\title{
Struktur Vegetasi Kawasan Hutan Alam dan Hutan Rerdegradasi di Taman Nasional Tesso Nilo
}

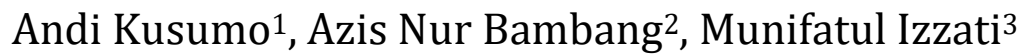 \\ 1Magister Ilmu Lingkungan, Universitas Diponegoro; email: akusoemo@yahoo.co.id \\ 2Dosen Magister Ilmu Lingkungan, Universitas Diponegoro \\ 3Jurusan Biologi, Fakultas Sains dan Matematika Universitas Diponegoro
}

\begin{abstract}
ABSTRAK
Hutan Tesso Nilo merupakan kawasan dengan tingkat keanekaragaman tanaman berpembuluh dan merupakan habitat bagi satwa terancam punah yaitu harimau sumatera (Panthera tigris sumatrae) dan gajah sumatera (Elephas maximus sumatranus). Kawasan ini tidak luput dari kegiatan perambahan dan di konversi menjadi perkebunan dan permukiman. Pembukaan lahan hutan akan mengakibatkan rusaknya fungsi hutan dan mengakibatkan musnahnya berbagai jenis flora dan fauna. Tujuan penelitian ini adalah untuk mengetahui akibat yang ditimbulkan oleh perambahan hutan terhadap strukur vegetasi kawasan hutan. Metode yang digunakan adalah survei dengan menggunakan sampling vegetasi petak dalam jalur dilokasi hutan alam dan hutan terdegradasi akibat perambahan. Hasil dianalisis untuk mengetahui kelimpahan vegetasi, indeks nilai penting dan indeks keanekaragaman (ShannonWiener). Hasil penelitian menunjukkan bahwa perambahan hutan mengakibatkan terjadinya perubahan pada struktur vegetasi. Perambahan mengakibatkan penurunan jumlah kelimpahan vegetasi, nilai keanekaragaman, dan dominansi jenis (indeks nilai penting) baik pada tingkat semai, pancang, tiang dan pohon.
\end{abstract}

Kata kunci: Taman Nasional Tesso Nilo, struktur vegetasi, perambahan

\begin{abstract}
Tesso Nilo forest is an area with a greater diversity of vascular plants and habitat for an endangered species, namely the Sumatran tiger (Panthera tigris sumatrae) and the Sumatran elephant (Elephas maximus sumatranus). This area was not spared from encroachment and conversion to plantations and settlements. Forest clearing will cause damage to forest functions and lead to the extinction of various species of flora and fauna. The purpose of this study was to determine the consequences caused by the encroachment of the structure of forest vegetation. The method used was a survey by sampling vegetation plots in the path of the location of natural forests and forests degraded due to encroachment. The results were analyzed to determine the abundance of vegetation, an index of the importance and diversity index (Shannon-Wiener). The results showed that deforestation resulted in a change in the structure of vegetation. Encroachment degrades an abundance of vegetation, the value of diversity, and dominance type (Importance Value Index) is good for seedlings, saplings, poles and trees.
\end{abstract}

Keywords: Nasional Park of Tesso Nilo, vegetation structure

Cara sitasi: Kusumo, A., Bambang, A. N., Izzati, M. (2016). Struktur Vegetasi Kawasan Hutan Alam dan Hutan Rerdegradasi di Taman Nasional Tesso Nilo. Jurnal Ilmu Lingkungan,14(1),19-26, doi:10.14710/jil.14.1.19-26

\section{PENDAHULUAN}

Hutan tropis Indonesia merupakan salah satu hutan tropis terluas didunia setelah Brazil di benua amerika selatan dan Kongo di benua afrika. Kelimpahan flora dan fauna hutan tropis di Indonesia sangat tinggi dan masih banyak yang belum teridentifikasi (Purba et al., 2014). Namun dengan meningkatnya jumlah manusia disekitar hutan menjadi ancaman bagi kelestarian hutan. Peningkatan jumlah manusia akan berbanding lurus dengan peningkatan kebutuhan sumberdaya seperti makanan, perlindungan, peralatan, lahan dan lain sebagainya (Purwaningsih et al. 2004). Tercatat sebanyak 10,2 juta masyarakat berada di dalam dan sekitar kawasan hutan (PHKA, 2007). Banyaknya masyarakat yang bermukim disekitar kawasan hutan dan meningkatnya kebutuhan akan sumberdaya meningkatkan laju konversi hutan. Menurut daryono (2009) dan Purba et al (2014) laju konversi hutan di Indonesia saat ini sangat tinggi yaitu sebesar 2 sampai dengan 2,8 juta hektar pertahun.

Hutan Tesso Nilo merupakan kawasan dengan tingkat keanekaragaman tanaman berpembuluh tinggi (Gillison, 2001). Hutan Tesso Nilo merupakan hutan dataran rendah yang tersisa di Sumatera dan merupakan habitat bagi satwa terancam punah yaitu harimau sumatera (Panthera tigris sumatrae) dan gajah sumatera (Elephas maximus sumatranus) (TNTN,2009). Kawasan hutan Tesso Nilo adalah kawasan hutan dataran rendah di Sumatera yang tidak luput dari 
kegiatan perambahan dan di konversi menjadi perkebunan dan permukiman (TNTN, 2009). Pembukaan lahan hutan akan mengakibatkan rusaknya fungsi hutan. rusaknya fungsi hutan dapat menimbulkan bencana dan kerugian bagi manusia.

Pembukaan dan perambahan hutan dengan cara dibakar adalah musnahnya berbagai jenis flora dan fauna (Purbowaseso, 2004). Tujuan penelitian ini adalah untuk mengetahui akibat yang ditimbulkan oleh perambahan hutan terhadap strukur vegetasi kawasan hutan. struktur vegetasi dilihat dari kelimpahan vegetasi dan tingkat keanekaragaman jenis pada kawasan hutan alam dan hutan terdegradasi di kawasan Taman Nasional Tesso Nilo. Hasil penelitian ini diharapkan dapat memberikann manfaat untuk merencanakan kegiatan rehabilitasi hutan dan lahan (RHL) dan informasi mengenai jenis-jenis yang dapat di pilih sebagai sumber benih untuk memperkaya lahan terdegradasi.

\section{METODE PENELITIAN}

Penelitian dilakukan di kawasan Taman Nasional Tesso Nilo, Kabupaten Pelalawan, Provinsi Riau. Lokasi dipilih pada kawasan hutan alam dan kawasan terdegradasi akibat perambahan. Penelitian dilakukan pada bulan Juni sampai Agustus 2015. Sampling vegetasi dilakukan dengan metode petak dalam jalur, dengan mencatat semua vegetasi yang ada berupa vegetasi bawah, semai, pancang, tiang dan pohon (Bismark, 2011; Fachrul 2012).

Pada metode ini dibuat jalur dengan petakpetak pengamatan yang terdiri dari petak ukuran 2 x 2 m yang digunakan untuk menganalisis vegetasi tingkat semai. Untuk petak $5 \times 5 \mathrm{~m}$ digunakan untuk menganalisis vegetasi tingkat pancang, petak ukuran $10 \times 10 \mathrm{~m}$ untuk analisis vegetasi tingkat tiang dan petak $20 \times 20 \mathrm{~m}$ digunakan untuk analisis vegetasi tingkat pohon yang digambarkan sebagai berikut.

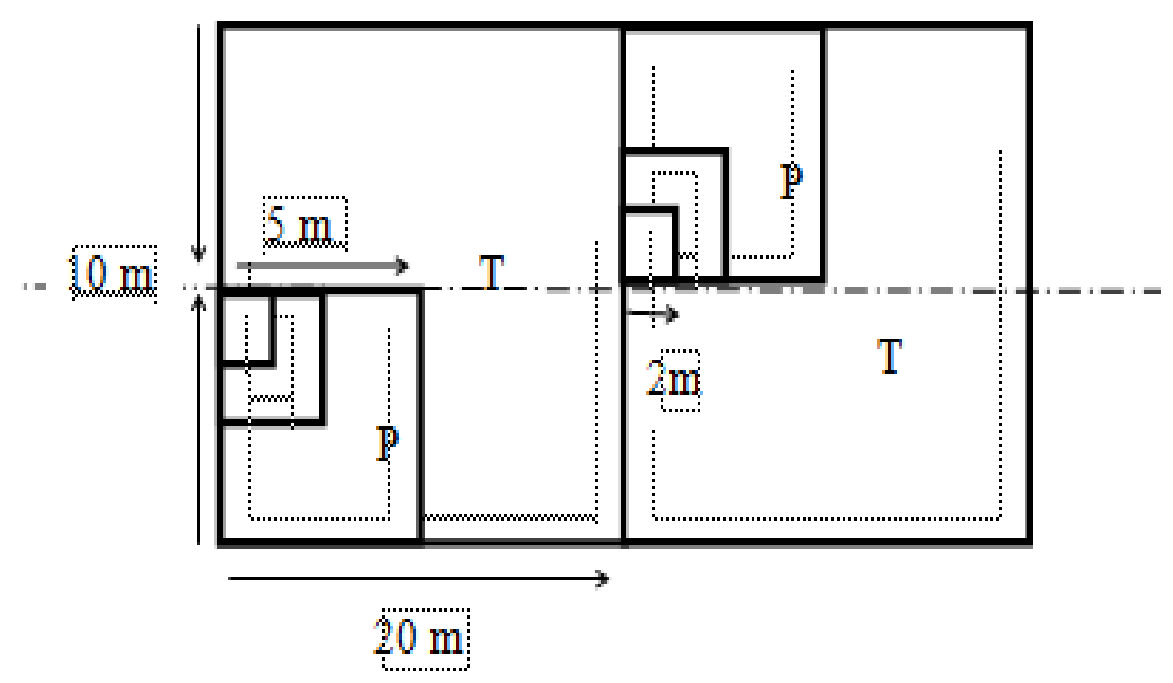

Gambar 1. Petak ukur vegetasi

Keterangan: $\mathrm{Sp}=$ Pancang $(5 \times 5 \mathrm{~m}), \mathrm{Sd}=$ Semai $(2 \times 2 \mathrm{~m}), \mathrm{T}=$ Pohon $(20 \times 20 \mathrm{~m}), \mathrm{P}=$ Tiang $(10 \times 10 \mathrm{~m})$ Sumber : (Bismark 2011; Fachrul 2012)

Pada masing-masing petak tersebut dilakukan pengukuran tinggi, diameter setinggi dada dan identifikasi jenis pohon, tiang, pancang, semai dan dicatat pada tally sheet yang telah disiapkan. Buku identifikasi mengacu pada buku identifikasi jenis pohon di hutan alam. Untuk jenis yang tidak dikenal pada hutan alam, dilakukan identifikasi melalui koleksi contoh herbarium (van Steenis et.al., 1975; Tjitrosoepomo, 2007; Yulianto 2014). Analisis dilakukan secara deskriptif. Jenis tanaman penutup tanah diambil pada titik sampel dan dilakukan identifikasi. Identifikasi dilakukan berdasarkan buku identifikasi tumbuhan. Hasil identifikasi jenis tumbuhan yang diperoleh dihitung nilai penting dan indeks keanekaragaman Shannon Weaver (Leksono, 2007; Fachrul 2012). Untuk menentukan persentase dan besarnya pengaruh yang diberikan suatu jenis tumbuhan terhadap komunitasnya, maka dicari indeks nilai penting menggunakan rumus sebagai berikut: (Indriyanto 2006; Leksono, 2007; Fachrul 2012). 
Kusumo, A., Bambang, A. N., Izzati, M. (2016). Struktur Vegetasi Kawasan Hutan Alam dan Hutan Rerdegradasi di Taman Nasional Tesso Nilo. Jurnal Ilmu Lingkungan,14(1),19-26, doi:10.14710/jil.14.1.19-26

$$
\begin{gathered}
\qquad N P=F R+K R+D R \\
\text { Frekuensi }(F)=\frac{\text { Jumlah plot yang ditempati suatu jenis }}{\text { Jumlah seluruh plot pengamatan }} \\
\text { Frekuensi relatif }(F R)=\frac{\text { Frekuensi suatu jenis }}{\text { Frekuensi total seluruh jenis }} \times 100 \% \\
\text { Kerapatan }(K)=\frac{\text { Jumlah individu suatu jenis }}{\text { Luas seluruh plot }} \\
\text { Kerapatan relatif }(K R)=\frac{\text { Kerapatan suatu jenis }}{\text { kerapatan total seluruh jenis }} \times 100 \% \\
\text { Dominansi }(D)=\frac{\text { Jumlah bidang dasar suatu jenis }}{\text { luas seluruh plot }} \\
\text { Dominansi relatif }(D R)=\frac{\text { Dominansi suatu jenis }}{\text { Dominansi total seluruh jenis }} \times 100 \%
\end{gathered}
$$

Untuk menentukan tingkat Keanekaragaman jenis tumbuhan menggunakan analisis indeks keanekaragaman ShannonWienner (Leksono 2007; Fachrul 2012).

Shannon Index: $\mathrm{H}^{\prime}=-\sum_{i=1}^{s} p i \ln p i$

Dimana:

$\mathrm{H}^{\prime}$ = keanekaragaman yang ingin diketahui

$\mathrm{Pi}=\mathrm{Ni} / \mathrm{N}$

$\mathrm{Ni}=$ jumlah individu setiap jenis

$\mathrm{N}=$ Jumlah total individu semua jenis

Indeks keanekaragaman jenis ShanonWhiener $\left(\mathrm{H}^{\prime}\right)$ dibagi menjadi 4 kategori. Indeks $\mathrm{H}^{\prime}=1-2$ dikategorikan rendah, indeks $\mathrm{H}^{\prime}=2-3$ dikategorikan sedang, indeks $\mathrm{H}^{\prime}=3-4$ dikategorikan tinggi, dan indeks $\mathrm{H}^{\prime}>4$ dikategorikan sangat tinggi.

\section{HASIL DAN PEMBAHASAN}

Hasil pengukuran vegetasi yang dilakukan pada pohon dan permudaannya (tiang, pancang dan semai). Teridentifikasi pada hutan alam memiliki jumlah jenis sebanyak 18 jenis untuk tingkat semai, 16 jenis untuk tingkat pancang, 15 jenis untuk tingkat tiang dan 34 jenis untuk tingkat pohon. Pada hutan terdegradasi memiliki jumlah jenis sebanyak 2 jenis untuk tingkat semai, 4 jenis untuk tingkat pancang, 5 jenis untuk tingkat tiang dan 5 jenis untuk tingkat pohon (Gambar 2). Sementara itu nilai keanekaragaman pada hutan alam sebesar 2.18 untuk tingkat semai, 2.05 untuk tingkat pancang, 2.34 jenis untuk tingkat tiang dan 3.05 untuk tingkat pohon. Pada hutan terdegradasi sebesar 0.05 untuk tingkat semai, 0.1 untuk tingkat pancang, 1.31 jenis untuk tingkat tiang, dan 1.16 untuk tingkat pohon (Gambar 3).

Hasil analisis vegetasi menunjukkan bahwa pada hutan alam memiliki jumlah jenis dan nilai indeks keanekaragaman yang lebih tinggi untuk tingkat pohon dan permudaannya (tiang, pancang, dan semai). Hal ini menunjukkan bahwa kegiatan pembukaan lahan terutama dengan pembukaan dengan cara pembakaran hutan mengakibatkan dampak yang besar. Dampak kebakaran hutan dapat memusnahkan berbagai macam jenis flora dan fauna (Purbowaseso, 2004).

Hutan di indonesia banyak di temukan tanaman yang bernilai ekonomi baik tanaman berkhasiat obat, nilai kayu, tanaman endemik bernilai estetika tinggi, pohon untuk bersarangnya lebah madu (pohon sialang), serta habitat bagi satwa langka terancam punah seperti gajah dan harimau sumatera. Oleh karena itu dampak kerugian yang diakibatkan oleh kebakaran hutan sangat mahal. Pangestu \& Ahmad (1998) didalam (Purbowaseso, 2004) menghitung dari hutan seluas 263.991 Ha hutan terbakar kerugian yang ditimbulkan adalah sebesar Rp. 23 Milyar untuk hilangnya bahan mentah dan bahan makanan, 27 Milyar akibat kehilangan sumberdaya genetik, dan 73 milyar akibat kerugian rekreasi. 


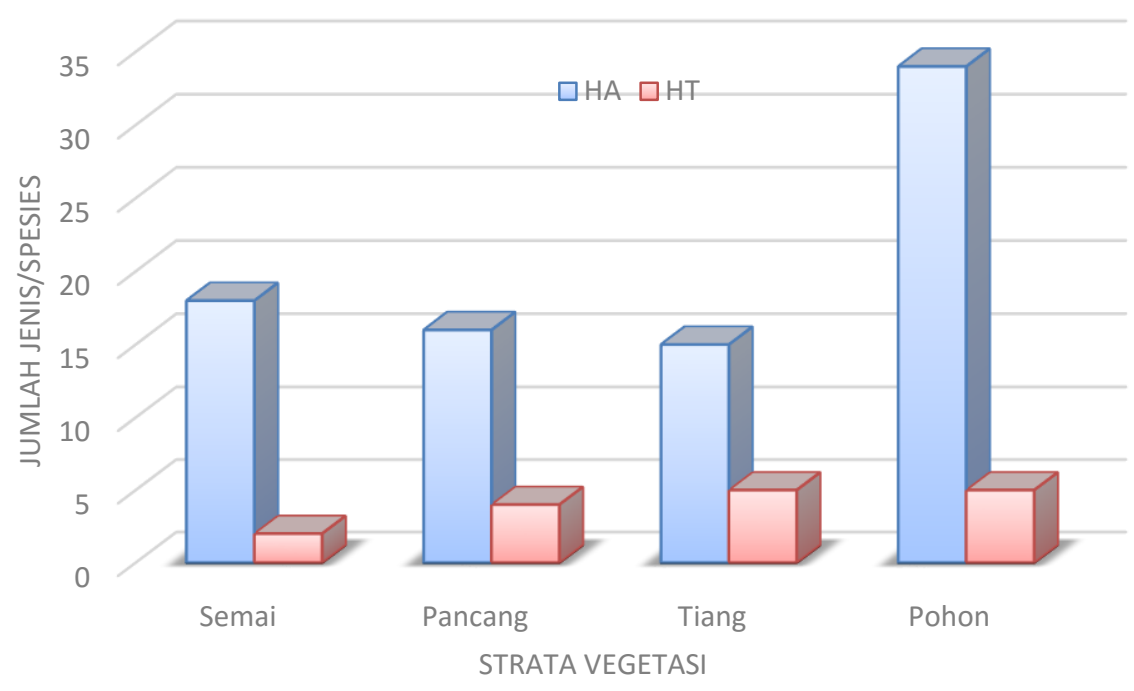

Gambar 2. Grafik jumlah jenis vegetasi pada plot ukur dalam tingkat pohon, tiang, pancang dan semai

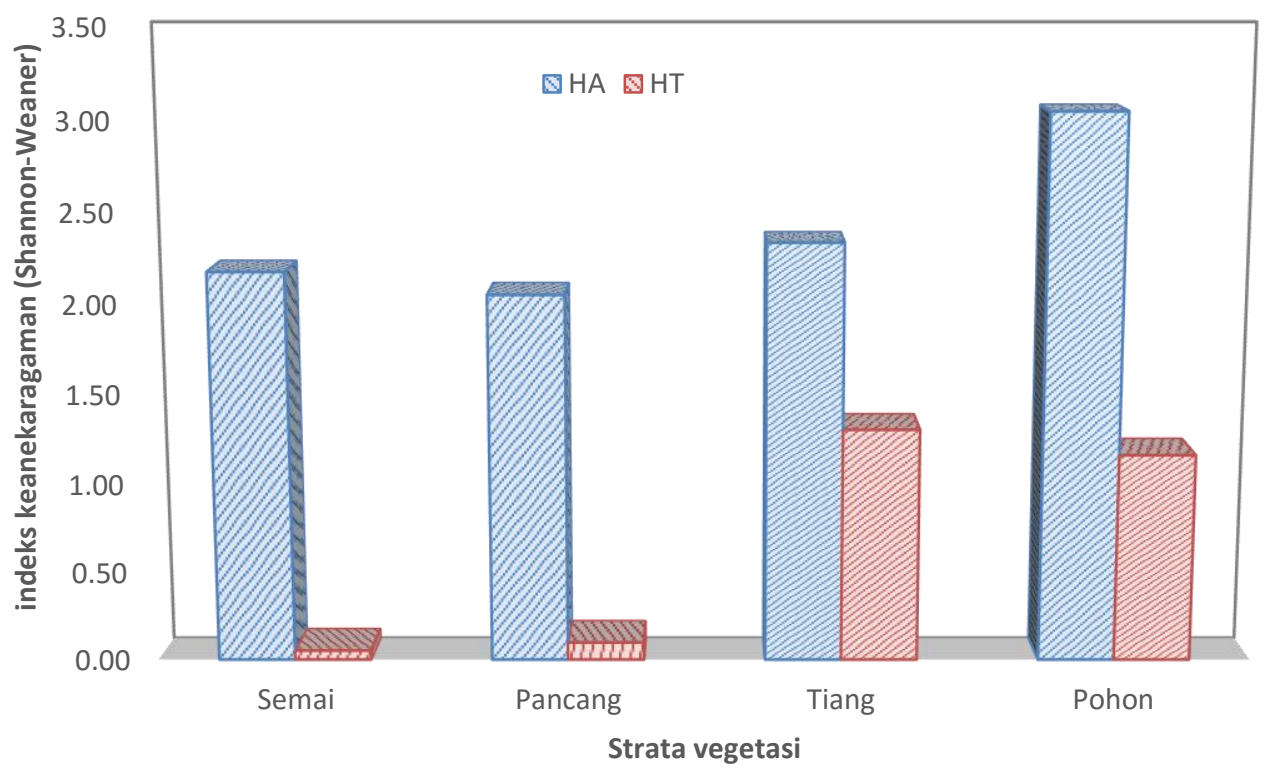

Gambar 3. Grafik Indeks keragaman vegetasi dalam tingkat pohon, tiang, pancang dan semai

Data penghitungan dan pengumpulan vegetasi pohon dan tingkat pertumbuhannya perlu didiskripsikan agar diketahui kondisi komunitas tumbuhan. Tiga parameter kuantitatif untuk mendeskripsikan kondisi komunitas tumbuhan yaitu densitas atau kerapatan, frekuensi dan dominansi atau kelindungan yang diukur melalui luas bidang dasar (basal cover) atau penutupan tajuk (canopy cover) (Indriyanto, 2006). Tumbuhan yang dominan memberikan ciri utama terhadap fisiognomi suatu komunitas hutan. Masing-masing parameter jenis jika dijumlahkan akan menghasilkan Indeks Nilai Penting (INP) yang menyatakan dominansi suatu jenis dalam suatu komunitas (Indriyanto, 2006). 
Kusumo, A., Bambang, A. N., Izzati, M. (2016). Struktur Vegetasi Kawasan Hutan Alam dan Hutan Rerdegradasi di Taman Nasional Tesso Nilo. Jurnal Ilmu Lingkungan,14(1),19-26, doi:10.14710/jil.14.1.19-26

Tabel 1. Nilai Penting (NP) vegetasi dalam tingkat pohon, tiang, pancang dan semai pada hutan alam dan hutan terdegradasi

\begin{tabular}{|c|c|c|c|c|}
\hline \multirow[b]{2}{*}{ No } & \multicolumn{2}{|c|}{ Hutan Alam } & \multicolumn{2}{|c|}{ Hutan Terdegradasi } \\
\hline & Nama Spesies & NP & Nama Spesies & NP \\
\hline \multicolumn{5}{|c|}{ Semai } \\
\hline 1 & Shorea leprosula & 58.78 & Acacia Mangium & 174.10 \\
\hline 2 & Syzigium garcinifolia & 19.01 & Garcinia parvifolia Miq & 25.90 \\
\hline 3 & Dacryodes costanta Lam & 17.20 & - & - \\
\hline 4 & Callophylum pulcherimum & 11.47 & - & - \\
\hline 5 & Litsea Firma Bi & 11.47 & - & - \\
\hline 6 & Hydnocarpus kunstleri & 9.51 & - & - \\
\hline 7 & Shorea Sp. & 7.62 & - & - \\
\hline 8 & Scorodocarpus borneensis & 7.62 & - & - \\
\hline 9 & Anyshophylla distica & 5.73 & - & - \\
\hline 10 & Vatica stapfiana & 5.73 & - & - \\
\hline 11 & Scapium macropodum & 5.73 & - & - \\
\hline 12 & Polyalthia sp & 5.73 & - & - \\
\hline 13 & Palaquium hexandrum & 5.73 & - & - \\
\hline 14 & Archidendron microcarpum & 5.73 & - & - \\
\hline 15 & Gymnacranthera bancana & 5.73 & - & - \\
\hline 16 & Porterandia anisophylla & 5.73 & - & - \\
\hline 17 & Lhitocarpus Indicus Roxb & 5.73 & - & - \\
\hline 18 & Parashorea aptera & 5.73 & - & - \\
\hline \multicolumn{5}{|c|}{ Pancang } \\
\hline 1 & Shorea leprosula & 61.83 & Acacia Mangium & 160.91 \\
\hline 2 & Dacryodes costanta Lam & 20.84 & $S P 1$. & 12.90 \\
\hline 3 & Polyalthia sp & 13.70 & Macaranga spp. & 13.30 \\
\hline 4 & Litsea Firma Bi & 12.06 & Parashorea aptera & 12.90 \\
\hline 5 & Cinnamomum Sp. & 12.06 & - & - \\
\hline 6 & Syzigium Sp2. & 12.06 & - & - \\
\hline 7 & Dialium platysephalum & 10.42 & - & - \\
\hline 8 & Syzigium garcinifolia & 10.42 & - & - \\
\hline 9 & Gymnacranthera bancana & 6.85 & - & - \\
\hline 10 & Palaquium hexandrum & 6.85 & - & - \\
\hline 11 & Anyshophylla distica & 6.85 & - & - \\
\hline 12 & Shorea Sp. & 5.21 & - & - \\
\hline 13 & Baccaurea macrocarpa & 5.21 & - & - \\
\hline 14 & Monocarpia marginalis & 5.21 & - & - \\
\hline 15 & Shorea macrantha & 5.21 & - & - \\
\hline 16 & Lhitocarpus Indicus Roxb & 5.21 & - & - \\
\hline \multicolumn{5}{|c|}{ Tiang } \\
\hline 1 & Shorea leprosula & 53.40 & Macaranga spp. & 95.22 \\
\hline 2 & Callophylum pulcherimum & 31.91 & Acacia Mangium & 74.16 \\
\hline 3 & Palaquium hexandrum & 30.80 & Macaranga sp1 & 52.70 \\
\hline 4 & Syzigium Sp2 & 22.89 & $S P 1$. & 42.17 \\
\hline
\end{tabular}




\begin{tabular}{|c|c|c|c|c|}
\hline \multirow[b]{2}{*}{ No } & \multicolumn{2}{|c|}{ Hutan Alam } & \multicolumn{2}{|c|}{ Hutan Terdegradasi } \\
\hline & Nama Spesies & NP & Nama Spesies & NP \\
\hline 5 & Syzigium garcinifolia & 22.89 & Litsea Firma Bi & 35.75 \\
\hline 6 & Dacryodes costanta Lam & 17.52 & - & - \\
\hline 7 & Dacryodes costanta Lam & 17.52 & - & - \\
\hline 8 & Artocarpus rigidus & 14.08 & - & - \\
\hline 9 & Ochanostachys amentacea & 14.08 & - & - \\
\hline 10 & Garcinia parvifolia & 14.08 & - & - \\
\hline 11 & Litsea Firma Bi & 13.05 & - & - \\
\hline 12 & Dialium platysephalum & 11.95 & - & - \\
\hline 13 & Artocarpus integer & 11.95 & - & - \\
\hline 14 & Scapium macropodum & 11.95 & - & - \\
\hline 15 & Horsfieldia wallichii & 11.95 & - & - \\
\hline \multicolumn{5}{|c|}{ Pohon } \\
\hline 1 & Shorea leprosula & 28.83 & Acacia Mangium & 95.35 \\
\hline 2 & Callophylum pulcherimum & 18.38 & Macaranga sp1 & 94.67 \\
\hline 3 & Syzigium garcinifolia & 18.38 & Litsea Firma Bi & 42.33 \\
\hline 4 & Syzigium Sp2. & 17.70 & Macaranga spp. & 35.11 \\
\hline 5 & Palaquium hexandrum & 16.14 & Sp2. & 32.53 \\
\hline 6 & Dacryodes costanta Lam & 13.51 & - & - \\
\hline 7 & Litsea Firma Bi & 11.72 & - & - \\
\hline 8 & Hydnocarpus kunstleri & 10.66 & - & - \\
\hline 9 & Baccaurea macrocarpa & 10.44 & - & - \\
\hline 10 & Ochanostachys amentacea & 10.23 & - & - \\
\hline 11 & Ixonanthes icosandra & 9.32 & - & - \\
\hline 12 & Xerospermum Sp. & 8.67 & - & - \\
\hline 13 & Durio carinatus Mast & 8.26 & - & - \\
\hline 14 & Scapium macropodum & 7.69 & - & - \\
\hline 15 & Porterandia anisophylla & 7.69 & - & - \\
\hline 16 & Dipterocarpus gracilis & 6.63 & - & - \\
\hline 17 & Garcinia parvifolia & 6.63 & - & - \\
\hline 18 & Melanarrhoea sp. & 6.25 & - & - \\
\hline 19 & Gluta aptera & 6.11 & - & - \\
\hline 20 & Archidendron microcarpum & 6.11 & - & - \\
\hline 21 & Monocarpia marginalis & 6.11 & - & - \\
\hline 22 & Cinnamomum Sp. & 6.11 & - & - \\
\hline 23 & Horsfieldia wallichii & 6.11 & - & - \\
\hline 24 & Palaquium stellanum & 6.11 & - & - \\
\hline 25 & Macaranga sp 2 & 5.63 & - & - \\
\hline 26 & Mesua nuda & 5.63 & - & - \\
\hline 27 & Dialium platysephalum & 5.40 & - & - \\
\hline 28 & Scorodocarpus borneensis & 5.40 & - & - \\
\hline 29 & Artocarpus rigidus & 5.19 & - & - \\
\hline 30 & Pimeleodendron griffitianum & 5.19 & - & - \\
\hline 31 & Gymnacranthera bancana & 4.98 & - & - \\
\hline
\end{tabular}


Kusumo, A., Bambang, A. N., Izzati, M. (2016). Struktur Vegetasi Kawasan Hutan Alam dan Hutan Rerdegradasi di Taman Nasional Tesso Nilo. Jurnal Ilmu Lingkungan,14(1),19-26, doi:10.14710/jil.14.1.19-26

\begin{tabular}{|r|l|r|l|l|}
\hline \multirow{2}{*}{ No } & \multicolumn{2}{|c|}{ Hutan Alam } & \multicolumn{2}{c|}{ Hutan Terdegradasi } \\
\cline { 2 - 6 } & \multicolumn{1}{|c|}{ Nama Spesies } & NP & Nama Spesies & NP \\
\hline 32 & Myristica lowiana & 4.98 & - & - \\
\hline 33 & Memecylom costatum & 4.98 & - & - \\
\hline 34 & Lhitocarpus Indicus Roxb & 4.98 & - & - \\
\hline
\end{tabular}

Nilai penting suatu jenis vegetasi pohon menyatakan nilai kerapatan, frekuensi dan dominansi suatu spesies sehingga akan terlihat peran vegetasi tersebut dalam suatu komunitas (Indriyanto, 2006). Dari data indeks nilai penting pada tabel 1 terlihat bahwa pada hutan alam tingkat semai, pancang, tiang, dan pohon memiliki indeks nilai penting tertinggi pada spesies Shorea leprosula, Syzigium garcinifolia, Dacryodes costanta Lam, Polyalthia sp, Callophylum pulcherimum, dan Palaquium hexandrum. Pada hutan terdegradasi tingkat semai, pancang, tiang, dan pohon memiliki indeks nilai penting tertinggi pada spesies Acacia Mangium, Garcinia parvifolia Miq, Parashorea aptera, Macaranga sp1, dan Macaranga spp.

Dinamika populasi dan dominansi pohon dipengaruhi oleh kematian, pertumbuhan dan rekrutmen. Ada banyak jenis pohon yang tidak mampu tumbuh dan berkembang di bawah naungan pohon induk. Manan (1980) dalam (Purwaningsih, 2005) mengatakan proses regenerasi dan pertumbuhan anakan beberapa jenis pohon adakalanya harus dimulai dari terbentuknya celah/ bukaan kanopi. Pada hutan alam Jenis Callophylum pulcherimum hanya ditemukan pada tingkat pohon dan tiang, hal ini dapat terjadi karena anakan jenis ini tidak mampu tumbuh dan berkembang dibawah naungan pohon. Sementara itu jenis Shorea leprosuladapat ditemukan pada tingkat pohon, tiang, pancang, dan semai. Keberadaan Shorea leprosula pada tiap tingkatan ini menunjukkan bahwa jenis ini mampu berkembang baik dibawah naungan pohon.

Pada hutan terdegradasi terlihat bahwa spesies Acacia Mangium mendominasi pada tingkat semai, pancang, tiang dan pohon. Spesies Acacia Mangium merupakan spesies invasif. Spesies ini bukan asli dari hutan hujan dataran rendah tesso nilo. Acacia mangium merupakan tanaman legum dikelompokkan pada famili leguminoseae, dikenal dengan nama akasia, mangium, black wattle, brown salwood. Pohon ini tersebar di daerah indonesia bagian timur, Papua New Guinea dan Queensland bagian utara. Pohon ini merupakan tumbuhan yang dapat beradaptasi dengan baik pada tanah tropis lembab, dataran rendah, tanah masam dengan pH 4,5 hingga 6,5 (Orwa et al., 2009; Krisnawati et al., 2011).

Menurut ISAC (Invasive Spesies Advisory Committee) spesies invasif adalah jenis biota yang tumbuh dan berkembang biak/mengintroduksi ke dalam ekosistem lain yang menyebabkan kerugian ekonomi atau kerusakan lingkungan atau membahayakan kesehatan manusia. Daerah terbuka akibat pembukaan lahan dan kebakaran hutan menjadi rentan dan diambil alih oleh spesies invasif (Sunaryo \& Girmansyah 2015). Pengaruh spesies invasif ini sangat besar terhadap ekosistem. spesies invasif dapat merusak spesies asli dan ekosistemnya, sehingga dapat memicu degradasi dan hilangnya suatu habitat.

Taman nasional di indonesia merupakan kawan konservasi ekosistem in situ untuk jenis biota baik flora dan fauna asli dan lokal setempat. Kawasan Taman Nasional Tesso Nilo yang diperuntukkan untuk konservasi gajah sumatera. Gajah sumatera membutuhkan habitat yang mampu menyokong kebutuhan pakan, perlindungan dan pergerakannya. Keberadaan spesies invasif yang tidak terkendali dapat mengakibatkan rusaknya habitat dan mendesak perkembangan dan pertumbuhan jenis tumbuhan asli yang merupakan sumber pakan gajah sumatera. Dengan berubahnya komposisi ekosistem dan rusaknya habitat oleh pembukaan lahan dan kehadiran spesies invasif tentunya dapat membahayakan kelangsungan keberadaan gajah sumatera di Taman Nasional Tesso Nilo.

\section{KESIMPULAN}

Hasil penelitian menunjukkan bahwa perambahan hutan mengakibatkan terjadinya perubahan pada struktur vegetasi.

- Pada hutan alam teridentifikasi memiliki jumlah jenis sebanyak 18 jenis untuk tingkat semai, 16 jenis untuk tingkat pancang, 15 jenis untuk tingkat tiang dan 34 jenis untuk tingkat pohon. Pada hutan terdegradasi memiliki jumlah jenis sebanyak 2 jenis untuk tingkat semai, 4 jenis untuk tingkat pancang, 5 jenis untuk tingkat tiang dan 5 jenis untuk tingkat pohon. 
- Indeks keanekaragaman Sahnnon-Wiener pada hutan alam sebesar 2.18 untuk tingkat semai, 2.05 untuk tingkat pancang, 2.34 jenis untuk tingkat tiang dan 3.05 untuk tingkat pohon. Pada hutan terdegradasi sebesar 0.05 untuk tingkat semai, 0.1 untuk tingkat pancang, 1.31 jenis untuk tingkat tiang, dan 1.16 untuk tingkat pohon.

- Indeks nilai penting pada hutan alam tingkat semai, pancang, tiang, dan pohon memiliki indeks nilai penting tertinggi pada spesies Shorea leprosula, Syzigium garcinifolia, Dacryodes costanta Lam, Polyalthia sp, Callophylum pulcherimum, dan Palaquium hexandrum. Pada hutan terdegradasi tingkat semai, pancang, tiang, dan pohon memiliki indeks nilai penting tertinggi pada spesies Acacia Mangium, Garcinia parvifolia Miq, Parashorea aptera, Macaranga sp1, dan Macaranga spp.

\section{DAFTAR PUSTAKA}

Bismark, M. (2011). Prosedur Operasional Standar (SOP) untuk survei keragaman jenis pada kawasan konservasi. Pusat Penelitian dan Pengembangan Kehutanan. Kementerian Kehutanan dan International Tropical Timber Organization. Bogor.

Daryono, H. 2009. "Potensi, Permasalahan Dan Kebijakan Yang Diperlukan Dalam Pengelolaan Hutan Dan Lahan Rawa Gambut Secara Lestari." Analisis Kebijakan Kehutanan 6 (1981): 71-101.

Fachrul, M. (2012). Metode sampling bioekologi. Bumi Aksara. Jakarta.

Gillison, A. (2001). Vegetation Survey and Habitat Assessment of the Tesso Nilo Forest Complex. Report Prepared for WWF-US. Jakarta

Indriyanto. (2006). Ekologi Hutan. PT Bumi Aksara. Jakarta.
Krisnawati, H., Kallio, M., \& Kanninen, M. (2011). Acacia Mangium Willd: Ecology silviculture and productivity. CIFOR. Bogor.

Leksono, A. (2007). Ekologi pendekatan deskriptif dan kuantitatif. Bayumedia Publishing. Malang.

Orwa, C, A Mutua, R Kindt, R Jamnadass, and S Anthony. $2009 . \quad$ "Acacia Mangium." http://www.worldagroforestry.org/treedb/AFTPDF S/Acacia_mangium.PDF. Diakses tanggal 30 November 2015.

PHKA, D. (2007). Pedoman Pemanfaatan Hasil Hutan Bukan Kayu Dalam Rangka Pemberdayaan Masyarakat Didalam dan Sekitar Kawasan Konservasi. (D. J. PHKA, Ed.)Buku pedoman. Direktorat Jenderal PHKA. Jakarta.

Purba, C. P. ., Nanggara, S. ., Ratriyono, M., Apriani, I., Rosalina, L., Sari, N. ., \& Meridian, A. . (2014). Potret keadaan hutan indonesia 2009 - 2013. Forest Watch Indonesia. Bogor.

Purbowaseso, B. (2004). Pengendalian Kebakaran Hutan. PT Rineka Cipta. Jakarta.

Purwaningsih, P. (2005). Species composition and vegetation structure in Pakuli area, Lore Lindu National Park, Central Sulawesi. Biodiversitas, Journal of Biological Diversity, 6(2), 123-128.

Purwaningsih, S., Hardiningsih, R., Wardah, W., \& Sujadi, A. (2004). Populasi Bakteri dari Tanah di Desa TuduAog , Kecamatan Population of bacteria from soil in Tudu-Aog village , Passi district, Bolaang Mongondow, Sulawesi Utara. BIODIVERSITAS, 5, 1316.

Sunaryo, \& Girmansyah, D. (2015). Identifikasi tumbuhan asing invasif di Taman Nasional Tanjung Puting , Kalimantan Tengah. Prosiding Seminar Nasional Masyarakat Biodiversitas Indonesia, 1, 1034-1039.

Tjitrosoepomo, G. (2007). Taksonomi tumbuhan spermatophyta. Gajah Mada University Press. Yogyakarta.

TNTN. 2009. Zonasi Taman Nasional Tesso Nilo. Balai Taman Nasional Tesso Nilo. Pelalawan - Riau.

Van Steenis, C. G. G. ., Bloembergen, S., \& Eyma, P. . (1975). Flora untuk sekolah di Indonesia. PT. Pradnya paramita. Jakarta.

Yulianto, K. (2014). Panduan lapangan pengenalan 101 jenis pohon hutan hujan dataran rendah. WWF Riau. Pekanbaru. 